\title{
Proses Pirolisis Sampah Plastik dalam Rotary Drum Reactor dengan Variasi Laju Kenaikan Suhu
}

\author{
Muhammad Sigit Cahyono $^{1 *}$, Maria Ratih Puspita Liestiono ${ }^{1}$, Cahyo Widodo ${ }^{2}$ \\ ${ }^{1}$ Prodi Teknik Perminyakan, ${ }^{2}$ Prodi Teknik Lingkungan \\ Universitas Proklamasi 45 \\ Jl.Proklamasi 01 Sleman Telp.(0274)558901 \\ Hp 081542843878, 085232809931, 081326905263 \\ Website : www.up45.ac.id, E-mail : sigitup45@gmail.com
}

\begin{abstract}
Abstrak - Sampah plastik merupakan salah satu jenis sampah yang bisa menimbulkan pencemaran lingkungan jika tidak bisa ditangani dengan baik. Salah satu metode untuk mengatasi masalah tersebut adalah dengan mengubahnya menjadi bahan bakar alternatif melalui proses pirolisis. Tujuan dari penelitian ini adalah untuk mengetahui pengaruh laju kenaikan suhu terhadap rendemen dan kualitas produk pirolisis sampah plastik di dalam Rotary Drum Reactor. Bahan baku yang digunakan adalah sampah plastik berupa tas kresek hitam yang bersih dan kering. Bahan tersebut dimasukkan ke dalam reaktor untuk dipanaskan sampai suhu $350^{\circ} \mathrm{C}$ selama satu jam menggunakan steamatomizing burner. Variabel dari penelitian ini adalah laju kenaikan suhu di dalam reaktor, yaitu 5 , 10, dan $15^{\circ} \mathrm{C} /$ menit. Hasil penelitian menunjukkan bahwa semakin tinggi laju kenaikan suhu, rendemen minyak yang dihasilkan juga semakin besar. Rendemen terbesar yaitu $46 \%$ yang dicapai pada laju kenaikan suhu $15^{\circ} \mathrm{C}$ menit. Hasil uji laboratorium menunjukkan bahwa karakteristik minyak hasil pirolisis mendekati sifat-sifat minyak solar, sehingga bisa dijadikan alternatif bahan bakar mesin diesel di masa depan.
\end{abstract}

Kata kunci: sampah plastik, pirolisis, rotary drum reactor, laju kenaikan suhu, steam-atomizing burner

\section{Pendahuluan}

Sampai saat ini, ketergantungan Indonesia terhadap Bahan Bakar Minyak (BBM) sangatlah tinggi. Pertumbuhan penduduk yang pesat dan perkembangan industri yang cepat, membuat konsumsi BBM semakin meningkat. Di dalam bauran energi nasional, minyak bumi bahkan menempati posisi teratas sebagai sumber energi yang dikonsumsi oleh masyarakat maupun industri. Di sisi lain, produksi minyak bumi kita cenderung stagnan dan ada kecenderungan menurun dalam beberapa dekade terakhir sehingga tidak bisa mencukupi kebutuhan BBM tersebut. Hal ini menyebabkan Indonesia harus mengimpor BBM dalam jumlah yang besar dari negara lain.

Untuk mengatasi permasalahan tersebut, berbagai macam cara telah dilakukan untuk mengatasi krisis energi, diantaranya adalah mengembangkan energi alternatif pengganti minyak bumi. Hal ini seperti dituangkan dalam Peraturan Pemerintah Nomor 79 Tahun 2014 tentang Kebijakan Energi Nasional (KEN) yang telah disahkan oleh Presiden Susilo Bambang Yudhoyono di akhir periode kepemimpinannya [11].

Melalui upaya konversi ke sumber energi baru terbarukan (EBT), diharapkan konsumsi minyak bumi yang sangat besar pada saat ini dapat berkurang secara signifikan. Ditargetkan, pada tahun 2025 nanti bauran energi dari EBT mencapai 23\% dari total konsumsi energi nasional, seperti ditunjukkan dalam Gambar 1.

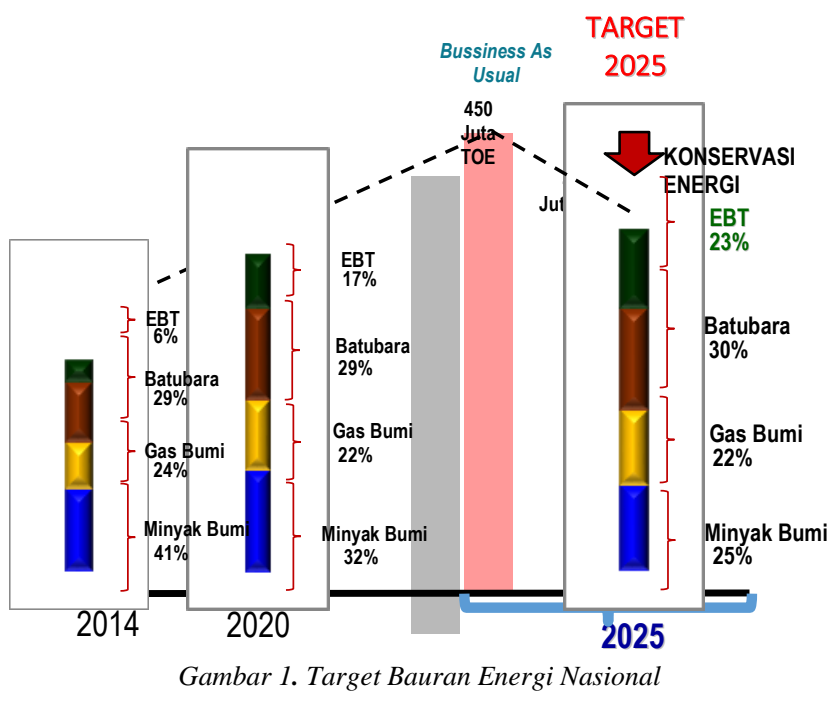

Sementara itu, pengembangan Iptek saat ini salah satunya difokuskan pada bidang energi baru dan terbarukan. Hal ini didasarkan pada tujuan pembangunan dan prioritas pembangunan Iptek yang ditetapkan dalam Rencana Pembangunan Jangka Menengah (RPJM) yang dikeluarkan oleh pemerintah. Berdasarkan kebijakan- 
kebijakan tersebut diatas, kita dapat melihat bahwa energi alternatif menempati posisi yang sangat penting dan menjadi perhatian besar dari pemerintah, terutama disaat krisis energi seperti saat ini [1].

Permasalahan lain di Indonesia yang sulit dipecahkan adalah masalah sampah. Penyebab utamanya adalah peningkatan jumlah penduduk yang sangat cepat diiringi dengan meningkatnya jumlah sampah yang dihasilkan, tanpa ada upaya perbaikan sistem pengelolaan sampah secara signifikan. Ada kecenderungan sampah-sampah tersebut hanya dibuang ke Tempat Pembuangan Akhir Sampah (TPA) tanpa pengolahan yang memadai, sehingga terjadi penumpukan sampah yang menyebabkan lahan TPA tersebut akan cepat terisi penuh.

Salah satu jenis sampah yang banyak ditemukan di TPA adalah sampah plastik. Sampah ini tidak bisa diuraikan oleh mikroorganisme sehingga harus didaur ulang agar tidak membahayakan lingkungan. Namun, tidak semua sampah bisa didaur ulang. Hanya sebagian saja yang bisa, terutama jenis PP, HDPE, dan PET. Sedangkan jenis lainnya sangat sulit didaur ulang karena tidak efisien, salah satunya adalah plastik jenis LDPE seperti tas kresek. Plastik jenis ini tidak diambil oleh pemulung karena harganya yang sangat murah sehingga banyak menumpuk di TPA.

Selain daur ulang, ada beberapa contoh proses pengolahan sampah plastik, diantaranya adalah pembakaran (combustion) dan pirolisis. Meskipun pembakaran dapat mengurangi jumlah sampah plastik secara signifikan, namun akan menimbulkan masalah baru yaitu munculnya emisi gas-gas beracun, seperti gas CO, furan, dioxin serta beberapa logam berat seperti kromium, tembaga, kobalt, selenium, timbal dan cadmium, dimana semua zat tersebut dapat mengganggu kesehatan bahan kematian bagi manusia [21]

Oleh karena itu, pengolahan sampah plastik secara pirolisis yang menghasilkan produk berupa cairan, gas, serta padatan diharapkan mampu menjadi salah satu alternatif dalam mengurangi masalah pencemaran lingkungan. Selain itu, melalui teknologi ini plastik dikonversi menjadi bahan bakar yang bisa dimanfaatkan sebagai sumber energi untuk keperluan rumah tangga maupun industri.

Proses pirolisis sendiri dipengaruhi oleh beberapa faktor, diantaranya adalah suhu selama proses pirolisis. Pirolisis yang bagus terjadi pada suhu antara $300^{\circ} \mathrm{C}$ sampai $500^{\circ} \mathrm{C}$. Semakin tinggi suhu pirolisis, jumlah minyak yang dihasilkan semakin besar. Akan tetapi, diatas suhu $500^{\circ} \mathrm{C}$, terjadi proses dekomposisi produk lebih lanjut menjadi gas sehingga minyak yang dihasilkan akan mulai berkurang. Selain itu, semakin tinggi suhu proses maka energi yang dibutuhkan untuk proses pirolisis juga semakin besar. Oleh karena itu, pengaturan suhu yang tepat akan sangat berpengaruh terhadap keberhasilan dan efisiensi dari proses pirolisis [9].

Selain suhu, laju pemanasan selama proses pirolisis juga berpengaruh terhadap jumlah dan kualitas produk yang dihasilkan. Tao, dkk (2013) melakukan proses pirolisis beberapa jenis plastik murni di dalam reaktor tubular furnace dengan variasi laju pemanasan $3,7^{\circ} \mathrm{C} /$ menit, $9^{0} \mathrm{C} /$ menit, $20,6^{\circ} \mathrm{C} /$ menit, dan $33,3^{\circ} \mathrm{C} /$ menit.
Hasil penelitian menunjukkan bahwa rendemen minyak akan meningkat seiring dengan kenaikan laju pemanasan, akan tetapi rendemen gas dan residu padatan akan menurun. Variasi dari distribusi senyawa di dalam minyak yang dihasilkan dari bermacam-macam plastik juga berbeda antara satu sama lain [18].

Sementara itu, penelitian terkait pengaruh laju pemanasan pada proses pirolisis sampah plastik yang didapatkan langsung dari TPA belum pernah dilakukan, padahal sampah plastik merupakan salah satu bahan utama yang didapatkan di TPA di Indonesia. Oleh karena itu, tujuan dari penelitian ini adalah untuk mengetahui pengaruh laju pemanasan terhadap rendemen dan karakteristik produk yang dihasilkan dari pirolisis sampah plastik dari TPA di dalam reaktor rotary drum. Melalui penelitian ini diharapkan bisa dihasilkan rumusan teknologi pirolisis yang paling efektif dan efisien dalam mengolah sampah anorganik menjadi produk-produk yang bisa dijadikan sebagai sumber energi alternatif bagi masa depan

\section{Dasar Teori}

Plastik adalah jenis makromolekul yang dibentuk dengan proses polimerisasi yaitu penggabungan beberapa molekul sederhana (monomer) melalui proses kimia menjadi molekul besar yang disebut dengan polimer [14]. Sampah plastik sukar diuraikan oleh mikroorganisme sehingga harus didaur ulang agar tidak membahayakan lingkungan. Sebagai contoh, sampah kantong plastik apabila ditimbun di dalam tanah, butuh sekitar 1000 tahun untuk sampah tersebut dapat terurai terdegradasi melalui mikroorganisme [1].

Senyawa utama material plastik adalah polyethylene. Senyawa ini terbentuk dari monomer-monomer ethylene yang dipolimerisasi dengan mekanisme radikal bebas yang biasa digunakan sebagai bahan pembuatan kantong plastik, botol plastik, atau pipa plastik [5]. Secara umum, jenis plastik ini bersifat halus, fleksibel, tahan air, mudah dibentuk dan diwarnai, serta harganya relatif murah. Rumus kimia dari polyethylene adalah (-CH2-)n, dengan $n$ sebagai derajat polimerisasi. Di pasaran, terdapat dua jenis polyethylene, yaitu jenis HDPE (High Density Polyethylene) dan LDPE (Low Density Polyethylene). Polyethylene jenis HDPE banyak dijumpai sebagai bahan pengemas untuk botol plastik minuman, sedangkan LDPE digunakan sebagai bahan baku pembuatan kantong plastik [13].

Proses daur ulang (recycling) menjadi sangat populer saat ini, dimana sampah plastik akan dilebur lagi menjadi bahan baku plastik dengan kualitas yang lebih rendah. Namun demikian, ada batasan kemampuan daur ulang plastik hingga kualitasnya menurun dan tidak dapat didaur ulang kembali. Oleh karena itu, dalam kenyataannya hanya sedikit dari sampah plastik yang dapat didaur ulang dan bahan hasil daur ulangnya juga mempunyai kualitas yang rendah sehingga dipandang tidak efisien. Oleh karena itu, perlu dipikirkan upaya lainnya agar sampah plastik bisa diolah menjadi bahan lain yang lebih bermanfaat, salah satunya menjadi bahan bakar minyak sintetis pengganti bensin, solar, atau bahan bakar minyak lainnya. Hal ini 
sangat mungkin dilakukan karena plastik sendiri berasal dari minyak bumi, sehingga hanya mengembalikannya ke bentuk semula. Di sisi lain, plastik juga mempunyai nilai kalor yang cukup tinggi, mencapai $40 \mathrm{MJ} / \mathrm{kg}$, setara dengan bahan bakar fosil seperti bensin dan solar [16].

Pirolisis merupakan suatu proses dekomposisi secara termokimia dari material organik atau sintetis untuk menghasilkan bahan bakar pada suhu tinggi dalam kondisi tanpa oksigen [17]. Proses ini dipengaruhi oleh beberapa faktor diantaranya adalah suhu dan waktu proses pirolisis. Pirolisis yang bagus terjadi pada suhu antara $370^{\circ} \mathrm{C}-420^{\circ} \mathrm{C}$ [19].

Dalam penerapan teknologi pirolisis terdapat parameter yang berpengaruh pada kecepatan reaksi dan mempunyai hubungan yang sangat kompleks, sehingga model matematis persamaan kecepatan reaksi pirolisis yang diformulasikan oleh setiap peneliti selalu menunjukkan rumusan empiris yang berbeda [20]. Produk pirolisis selain dipengruhi oleh suhu dan waktu, juga oleh laju pemanasan [10].

Proses pirolisis melibatkan tiga mekanisme dekomposisi, yaitu pemotongan rantai polimer yang lebih pendek, pemotongan pada ujung rantai dimana molekul kecil dan rantai panjang polimer akan terbentuk, dan pemisahan rantai polimer membentuk molekul-molekul kecil. Proses ini umumnya berlangsung secara simultan. Secara ilmiah, pirolisis adalah proses dekomposisi termal bahan organik pada temperatur sekitar 350 - 5500C tanpa adanya oksigen [3]. Produk utama dari proses dekomposisi termal plastik adalah minyak yang setara dengan bahan bakar konvensional.

Menurut Syamsiro (2015), secara umum minyak plastik dapat digunakan untuk menggantikan bahan bakar solar di mesin diesel baik sebagai bahan bakar tunggal maupun campuran dengan solar. Nilai kalor yang tidak berbeda jauh menjadikan minyak plastik layak digunakan sebagai pengganti solar. Namun demikian, ada beberapa sifat yang harus diperbaiki untuk meningkatkan performanya [15].

Selain minyak, produk hasil pirolisis plastik adalah gas yang tidak dapat dikondensasiskan (non-condensable gas). Gas hasil samping proses pirolisis dikarakterisasi menggunakan alat GC dengan detektor TCD dan FID. Komposisi gas hasil pirolisis terdiri dari hidrogen, karbon monoksida, karbon dioksida, metana, etana, propana, butana, dan pentana [7]. Gas ini kebanyakan dikembalikan lagi sebagai bahan bakar reaktor pirolisis untuk mengurangi penggunaan bahan bakar dari luar (autothermal system).

Ada sejumlah publikasi penelitian yang dibuat berdasarkan potensi dari berbagai macam plastik untuk produksi bahan bakar cair melalui proses pirolisis. Yang harus dicatat bahwa hasil dan kualitas dari produk sangat bergantung pada pengaturan beberapa parameter. Parameter utama adalah suhu, tipe reaktor, waktu tinggal, tekanan, dan penggunaan katalis [12]. Akan tetapi, percobaan TGA menunjukkan bahwa laju kenaikan suhu merupakan hal yang penting dalam reaksi penguraian molekul plastik [6].

Beberapa penelitian tentang pirolisis sampah plastik menjadi produk cair berkualitas bahan bakar menunjukkan hasil yang cukup bagus. Namun, sampai saat ini implementasi teknologi tersebut di Indonesia masih belum maksimal. Hal ini disebabkan karena kebutuhan energi untuk memanaskan reaktor pirolisis cukup besar, sehingga membutuhkan sumber bahan bakar dari luar seperti bahan bakar minyak (BBM), gas maupun biomasa. Penggunaan bahan bakar eksternal ini menyebabkan proses tidak bisa efisien sehingga merugikan pengelola teknologi tersebut.

Alternatif terbaik untuk lebih mengefisiensikan proses adalah penggunaan produk samping dari proses pirolisis, seperti minyak yang kualitasnya rendah sebagai bahan bakar reaktornya sendiri (Autothermal System). Sistem ini akan berjalan optimal jika menggunakan alat pembakaran yang tepat. Alat bakar yang digunakan untuk mengetahui karakteristik pembakaran bahan bakar cair adalah burner yang berfungsi untuk mengatomisasi bahan bakar agar mudah terbakar.

Teknik vaporasi cocok untuk bahan bakar minyak ringan (light fuel oil), sedangkan untuk minyak yang mempunyai viskositas tinggi, seperti minyak pirolisis plastik, diperlukan pemanasan awal atau atomisasi dari minyak ke dalam aliran udara dengan menggunakan atomizing burner. Salah satu jenis burner yang bisa digunakan untuk pembakaran minyak dengan viskositas tinggi adalah Steam-atomizing Burner, dengan prinsip kerja seperti ditunjukkan dalam Gambar 2 berikut.

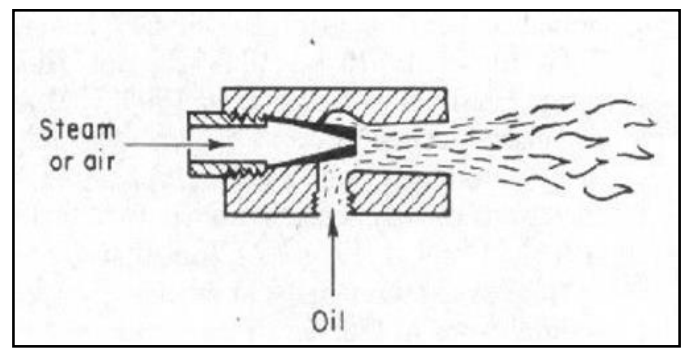

Gambar 2. Prinsip kerja steam-atomizing burner

Pada burner ini, proses atomisasi bahan bakar menggunakan uap panas bertekanan tinggi dari injector atau venture sebesar $3-12 \mathrm{~kg} / \mathrm{cm}^{2}$. Prinsip kerjanya adalah minyak yang baru keluar dari lubang saluran, dipecahpecah menjadi butiran-butiran kabut, tepat di depan mulut pembakar (nozzle). Lubang-lubang untuk keluarnya udara atau uap arahnya dibuat tangensial terhadap aliran minyak yang keluar dari lubang salurannya. Hal ini akan menimbulkan pusaran (swirl) campuran minyak dan udara di depan mulut burner. Gaya sentrifugal yang timbul akibat dari pusaran campuran minyak dan udara akan membantu proses pengabutan, sehingga akan diperoleh nyala api yang besar [4].

\section{Metodologi Penelitian}

a. Penyiapan alat

- Tahap pertama dari penelitian adalah penyiapan alat pirolisis.

- Peralatan yang digunakan dalam penelitian ini adalah sebuah reaktor pirolisis tipe rotary drum yang dilengkapi dengan sebuah siklon, dua buah kondensor dan satu penampung gas. Sebagai 
sumber energi, digunakan steam-atomizing burner yang berfungsi untuk membakar minyak pirolisis mengahasilkan panas untuk proses pirolisis.

- Peralatan yang digunakan ditunjukkan dalam gambar 3 berikut.

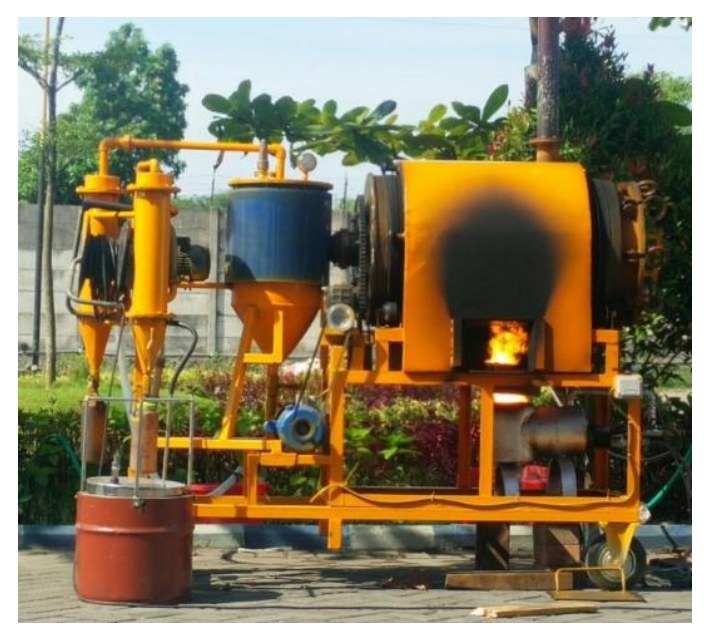

b. Penyiapan bahan

Gambar 3. Satu Set Alat Pirolisis

- Tahap berikutnya adalah penyiapan bahan.

- Bahan baku sampah plastik berupa tas kresek hitam diambil dari pengepul sampah yang ada di sekitar TPA Piyungan, Bantul. Sedangkan bahan bakar untuk proses pemanasan awal berupa oli bekas didapatkan dari bengkel motor yang ada di sekitar Kaliurang, Sleman.

- Bahan baku sampah plastik dibersihkan dari pengotor dan dikeringkan dengan cara dijemur dibawah sinar matahari selama sehari agar benarbenar kering dan kadar airnya berkurang.

- Setelah kering dan bersih, bahan baku ditimbang sesuai dengan kebutuhan yaitu $8 \mathrm{~kg}$ bahan baku untuk satu kali proses pirolisis.

c. Percobaan utama

- Tahap utama dari penelitian ini adalah proses pirolisis sampah plastik.

- Bahan baku dimasukan ke tabung pirolisis (retort), kemudian tutup tabung dipasang rapat. Kondensor diisi air menggunakan pompa dari penampung air yang disirkulasi sebagai pendingin pada kondensor.

- Setelah semua peralatan siap, steam-atomizing burner dinyalakan dengan bahan bakar oli bekas sebagai awalan. Setelah terbentuk minyak pirolisis, sebagian minyak tersebut digunakan sebagai bahan bakar dan sebagian lagi disimpan untuk dianalisa di laboratorium.

- Untuk mendapatkan laju kenaikan suhu di dalam reaktor sesuai variabel, yaitu sebesar 5, 10, dan $15^{\circ} \mathrm{C} /$ menit, penyalaan burner diatur sedemikian rupa melalui penggunaan steamnya, agar tercapai suhu pirolisis sesuai yang diinginkan.

- Proses pirolisis dilakukan sampai suhu stabil yaitu $350^{\circ} \mathrm{C}$ selama total 2 jam.

- Pada proses pirolisis, plastik akan meleleh dan menguap menjadi uap hidrokarbon, mengalir melalui pipa ke kondensor dan mengalami kondensasi menjadi minyak pirolisis dan ditampung dalam wadah penampung. Sebagian gas yang tidak terkondensasi akan direcycle ke kiln untuk memanaskan bahan di dalam retort.

- Proses pirolisis dihentikan ketika tidak ada lagi gas yang keluar dari kondensor. Kemudian alat dimatikan dan didiamkan sampai mendekati suhu kamar. Setelah itu tutup dibuka dan arang dikeluarkan dari dalam reaktor.

d. Analisa produk pirolisis

- Minyak plastik yang terbentuk kemudian ditampung dalam wadah penampung untuk diukur volumenya dan diuji karakteristiknya di dalam laboratorium. Begitu juga padatan yang tersisa akan ditimbang untuk diketahui massanya. Sedangkan rendemen gas yang tidak terkondensasi (noncondensable gas), akan dihitung dari selisih massa bahan baku dengan massa minyak dan padatan yang dihasilkan.

- Uji karakteristik produk cair dilakukan di Laboratorium Teknologi Minyak Bumi, Gas dan Batubara, Departemen Teknik Kimia UGM, dengan parameter Specific Gravity (ASTM D 1298), Viscosity Kinematic (IKU/5.4/TK-02), Flash Point (ASTM D 92), Pour Point (ASTM D 97), dan Nilai kalori (D-5865-10a).

- Uji karakteristik produk padat dilakukan di Laboratorium Konversi Energi, Pusat Antar Universitas UGM, menggunakan metode ASTM D 1762 untuk kadar air, kadar abu, kadar volatile matter dan kadar karbon terikat.

- Sementara untuk gas hasil pirolisis (noncondensable gas), pengujian dilakukan di Laboratorium Analisis Instrumentasi, Departemen Teknik Kimia UGM, menggunakan peralatan Gas Chromatography - Mass Spectroscopy (GC-MS) untuk mengetahui kandungan gas hidrogen, karbon monoksida, karbondioksida, dan gas metana yang ada di dalamnya.

\section{Temuan dan Pembahasan}

\subsection{Distribusi Suhu Proses Pirolisis}

Pengujian proses pirolisis sampah plastik dengan variasi laju kenaikan suhu, didapatkan hasil pengujian berupa distribusi suhu selama proses pirolisis seperti ditunjukkan dalam gambar 4 berikut.

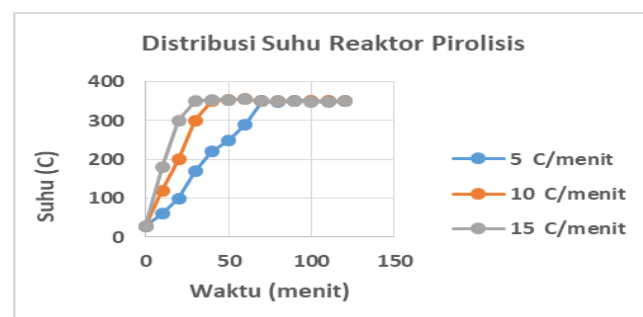

Grafik 4. Grafik pengamatan suhu reaktor selama proses pirolisis sampah plastik

Berdasarkan gambar 4, dapat dilihat bahwa semakin besar laju pemanasan, maka suhu proses pirolisis $\left(350^{\circ} \mathrm{C}\right)$ 
akan lebih cepat tercapai. Pada laju kenaikan suhu $5^{0} \mathrm{C} /$ menit, suhu proses pirolisis akan tercapai setelah 75 menit proses pemanasan, sedangkan pada laju kenaikan suhu 10 dan $15^{\circ} \mathrm{C} /$ menit, suhu proses pirolisis akan tercapai setelah 35 dan 20 menit proses pemanasan.

Adanya perbedaan laju kenaikan suhu ini disebabkan karena pengaturan tekanan pada steam-atomizing burner yang berbeda, dimana tekanan steam yang besar akan meningkatkan laju pemanasan sehingga suhu proses pirolisis bisa tercapai dalam waktu yang diinginkan.

\subsection{Pengaruh Laju Pemanasan terhadap Rendemen Proses} Pirolisis

Di sisi lain, laju kenaikan suhu juga akan berpengaruh terhadap rendemen produk yang dihasilkan, seperti terlihat dalam gambar 5 berikut.

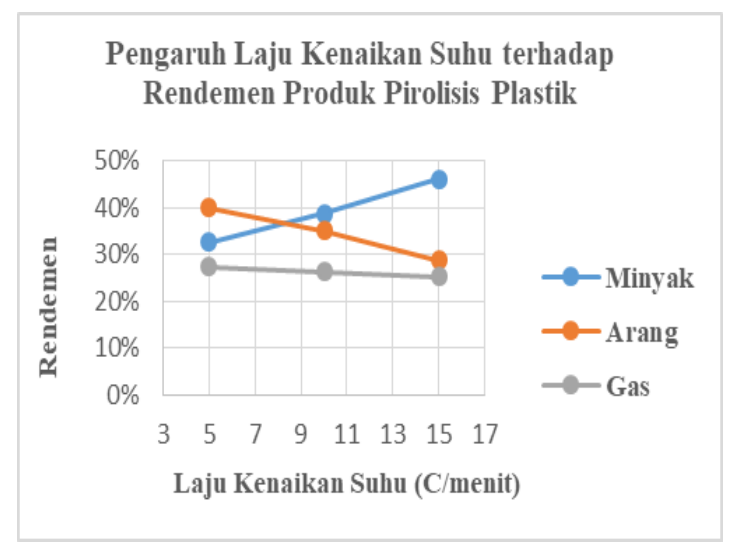

Grafik 5. Pengaruh laju kenaikan suhu terhadap rendemen produk pirolisis sampah plastik

Berdasarkan Gambar 5 dapat dilihat bahwa semakin besar laju pemanasan maka rendemen minyak akan semakin besar, sedangkan rendemen gas dan padatan semakin kecil. Rendemen minyak terbesar yaitu $46 \%$ dihasilkan dari proses pirolisis dengan laju pemanasan $15^{\circ} \mathrm{C} /$ menit pada suhu $350^{\circ} \mathrm{C}$, dimana pada proses tersebut rendemen gas dan padatan adalah yang terkecil, sebesar $25,2 \%$ dan $28,8 \%$.

Adanya tren kenaikan produk minyak dan penurunan produk gas dan padatan hasil proses pirolisis ini sesuai dengan penelitian yang dilakukan oleh Tao dkk. (2013). Menurut mereka, pirolisis bisa dilihat sebagai sebuah proses untuk mengeluarkan bahan-bahan mudah menguap dari sampah plastik. Lebih spesifik lagi, jika suhu proses sangat tinggi, maka bahan organik dengan titik didih dan berat molekul yang besar, yang selama ini tertinggal sebagai bagian dari residu padatan, akan terlepas dalam bentuk gas yang menguap. Pada akhirnya, gas-gas yang menguap tersebut akan terkondensasi menjadi minyak [18].

Sementara untuk residu padatan, berupa campuran karbon dan abu yang akan tertinggal setelah proses pirolisis selesai dilakukan sesuai yang direncanakan. Adanya kenaikan hasil minyak dan penurunan hasil gas seiring dengan kenaikan laju pemanasan, disebabkan karena cepatnya laju pemanasan akan mengakselerasi pelepasan dan ekspansi termal dari bahan-bahan yang mudah menguap tersebut. Oleh karena itu, bahan tersebut akan cepat keluar dari dalam reaktor. Dengan kata lain, waktu tinggal dari minyak dalam bentuk uap semakin singkat. Sebagai akibatnya, reaksi degradasi sekunder dari minyak akan bisa ditekan, sehingga hasil minyaknya juga besar dan gasnya lebih sedikit.

Hasil penelitian ini juga tidak jauh berbeda dengan penelitian yang dilakukan oleh Liestiono (2017). Percobaan yang dilakukan menggunakan reaktor jenis fixed-bed untuk pirolisis sampah plastik berupa tas kresek, menunjukkan hasil bahwa semakin besar laju pemanasan maka rendemen minyak akan semakin besar, sedangkan rendemen gas dan padatan semakin kecil. Rendemen minyak terbesar yaitu $35,83 \%$ dihasilkan dari proses pirolisis dengan laju pemanasan $6^{\circ} \mathrm{C} /$ menit pada suhu $350^{\circ} \mathrm{C}$, dimana pada proses tersebut rendemen gas dan padatan adalah yang terkecil, sebesar $5,83 \%$ dan $58,33 \%$ [8].

Adanya kenaikan hasil minyak dan penurunan hasil gas seiring dengan kenaikan laju pemanasan, disebabkan karena cepatnya laju pemanasan akan mengakselerasi pelepasan dan ekspansi termal dari bahan-bahan yang mudah menguap tersebut. Oleh karena itu, bahan tersebut akan cepat keluar dari dalam reaktor. Dengan kata lain, waktu tinggal dari minyak dalam bentuk uap semakin singkat. Sebagai akibatnya, reaksi degradasi sekunder dari minyak akan bisa ditekan, sehingga hasil minyaknya juga besar dan gasnya lebih sedikit.

Sifat-sifat fisis minyak hasil pirolisis hampir sama dengan hasil penelitian Yuliansyah (2015). Menurut mereka, didapatkan kemiripan karakter minyak hasil pirolisis dengan kerosin. Walaupun secara karakteristik bila ditinjau dari Gross Heating Value dan viskositasnya, minyak hasil pirolisis mirip dengan kerosin, namun hasil pirolisis plastik pada umumnya memiliki beberapa kandungan hidrokarbon dalam minyaknya, yakni kerosin (C10 s/d C16); Solar (C14 s/d C20); Gas Oil (C1 s/d C4); dan Fuel oil (C20 s/d C70), sehingga untuk memperoleh produk yang lebih spesifik sesuai yang dikehendaki, biasanya dilakukan destilasi lebih lanjut pada unit pemurnian [22].

\section{Simpulan}

Semakin besar laju pemanasan, maka suhu proses pirolisis $\left(350^{\circ} \mathrm{C}\right)$ akan lebih cepat tercapai. Pada laju kenaikan suhu $5^{\circ} \mathrm{C} /$ menit, suhu proses pirolisis akan tercapai setelah 75 menit proses pemanasan, sedangkan pada laju kenaikan suhu 10 dan $15^{\circ} \mathrm{C} /$ menit, suhu proses pirolisis akan tercapai setelah 35 dan 20 menit proses pemanasan.

Di sisi lain, semakin tinggi laju kenaikan suhu, maka rendemen minyak yang dihasilkan dari proses pirolisis plastik semakin besar, sedangkan rendemen arang dan gas akan semakin kecil. Rendemen minyak terbesar yaitu 46\% dihasilkan dari proses pirolisis dengan laju pemanasan $15^{\circ} \mathrm{C} /$ menit pada suhu $350^{\circ} \mathrm{C}$, dimana pada proses tersebut rendemen gas dan padatan adalah yang terkecil, sebesar $25,2 \%$ dan $28,8 \%$. 


\section{Kepustakaan}

[1] Bappenas. Buku Rencana Pembangunan Jangka Menengah Nasional 2015 - 2019. Jakarta : Bappenas. (2014).

[2] Bashir, N. H. H. Plastic problem in Africa. Japanese Journal of Veterinary Research, 61, pp. 1-11. (2013).

[3] Cahyono, M.S., Pengaruh Jenis Bahan pada Proses Pirolisis Sampah Organik menjadi Bio-oil sebagai Sumber Energi Terbarukan. Jurnal Sains dan Teknologi Lingkungan. Volume 5, Nomor 2, Juni 2013. Hal.67-76. (2013).

[4] Curtis, A. Assesment of The Effect of Cumbustion Waste Oil, and Health Effect Associated with The Use of Waste Oil as a Dust Supresant. USA : Woodward Clyde. Ltd. (2001).

[5] Fessenden, R.J. Kimia Organik I, pp. 23 - 51. (1982)

[6] Kayacan, I., \& Dogan, O. M., Pyrolysis of Low and High Density Polyethylene, Part I: Non-isothermal Pyrolysis Kinetics. Energy Sources, Vol. 30, pp. 385-391. (2008).

[7] Kuncser, R, Paraschiv, M., Tazerout, M. \& Bellettre, J. Liquid Fuel Recovery Through Pyrolysis of Polyethylene Waste. Environmental Engineering and Management Journal 9 (10) : 1371-74. (2010).

[8] Liestiono, M.R.P., Cahyono, M.S., Widyawidura, W., Prasetya, A., Syamsiro, M., Karakteristik Minyak Dan Gas Hasil Proses Dekomposisi Termal Plastik Jenis Low Density Polyethylene (LDPE), Jurnal OFFSHORE, Volume 1 No. 2 Desember $2017: 1$ -9 .

[9] Mandala, W. W., Cahyono, M.S., Maarif, S., Sukarjo, H., \& Wardoyo, Influence of Temperature to Yield and Caloric Value of Plastic Waste Pyrolysis Oil, Jurnal Mekanikal dan Sistem Termal, Vol. 1, no. 2, 2016.

[10] Rodiansono, Trisunaryanti, W., \& Triyono, Pembuatan, Karakterisasi dan Uji Aktifitas Katalis niMo/Z pada Reaksi Hidrorengkah Fraksi Sampah Plastik menjadi Fraksi Bensin, Berkala MIPA, 17, 2. (2007).

[11] Sekretariat Negara RI, Peraturan Pemerintah No. 79 Tahun 2014 tentang Kebijakan Energi Nasional, Jakarta (2014).
[12] Sharuddin, S., Abnisa, F., Daud, W.M.A.W., \& Aroua, M.K., A Review on Pyrolysis of Plastic Wastes. Energy Conversion and Management, Vol. 115, p. 308-326. (2016).

[13] Sumarni, \& Purwanti, A. Kinetika Reaksi Pirolisis Plastik Low Density Poliethylene (LDPE), Jurnal Teknologi, 1(2), pp. 135 140. (2008).

[14] Surono, U. B., Ismanto, Pengolahan Sampah Plastik Jenis PP , PET dan PE Menjadi Bahan Bakar Minyak dan Karakteristiknya, Jurnal Mekanika Dan Sistem Termal, 1(1), pp. 32-37. (2016).

[15] Syamsiro, M., Kajian Pengaruh Penggunaan Katalis Terhadap Kualitas Produk Minyak Hasil Pirolisis Sampah Plastik. Jurnal Teknik Vol.5 No.1 April 2015.

[16] Syamsiro, M., Arbiyantoro. Pengolahan Sampah Plastik dari TPA Piyungan menjadi Bahan Bakar Minyak. Jurnal Riset Daerah Vol XIII, No.3. Desember 2014.

[17] Syamsiro, M., Saptoadi, H., Norsujianto, T., Noviasri, P., Cheng, S., Alimuddin, Z., \& Yoshikawa, K. Fuel Oil Production from Municipal Plastic Wastes in Sequential Pyrolysis and Catalytic Reforming Reactors. Energy Procedia, Volume 47, pp. 180-188. (2014).

[18] Tao, P., Ma, X.B., Chen, D., Wang, H., Pyrolysis of Waste Plastics : Effect of Heating Rate on Product Yields and Oil Properties, Advanced Material Research 666:1-10, February 2013.

[19] Thorat, P. V, Warulkar, S., \& Sathone, H. Pyrolysis of waste plastic to produce Liquid Hydroocarbons, Advances in Polymer Science and Technology, 3(1), pp. 14-18. (2013).

[20] Trianna, N.W. \& Rochimoellah, M., Model Kinetika Reaksi Heterogen pada Pirolisis., Prosiding Rekayasa Kimia dan Proses, ISSN 1411-4216, B-16, UNDIP. (2002).

[21] Verma, R., Vinoda, K. S., Papireddy, M., \& Gowda, A. N. S Toxic Pollutants from Plastic Waste - A Review, Procedia Environmental Sciences, 35, 701-708, 2016 , http://doi.org/10.1016/j.proenv.2016.07.069.

[22] Yuliansyah, A.T., Prasetya, A., Ramadhan, M.A.A., \& Laksono, R. Pyrolysis of Plastic Waste to Produce Pyrolytic Oil As an Alternative Fuel. International Journal of Technology (2015) 7 : 1076-1083.

(2015). 